\title{
LESによるキャビティーせん断乱流構造 の数値シミュレーション
}

\author{
NUMERICAL SIMULATION ON TURBULENT STRUCTURES IN CAVITY \\ FLOWS BY MEANS OF LARGE EDDY SIMULATION
}

\author{
禰津家久 1 ・ 山本義暢 2 ・鬼束幸樹 3 \\ Iehisa NEZU, Yoshinobu YAMAMOTO and Kouki ONISTUKA \\ 1正会員 工博 京都大学大学院教授 睘境地球工学教室 (テ606-8501 京都市左京区吉田本町) \\ 2学生員 京都大学大学院生 工学研究科環境地球工学尃攻 \\ 3 正会員 博(工) 京都大学大学院助手 環境地球工学教室
}

\begin{abstract}
This paper describes the numerical simulation results of cavity in open-channel flows by means of Large Eddy Simulation(LES). The comparison, between numerical simulation and turbulence measurements conducted by making use of a two component fiber-optic laser Doppler anemometer (FLDA), was carried out in two cases. The results indicate that LES can reproduce the variations of mean velocities and turbulent statistics by trench length changes, and these variations may be relevant to the cycle of separated vortices and the position and size of the large circulating vortex.
\end{abstract}

Key Words : cavity flow, LES, FLDA, turbulence structure, mean velocity, separated vortices, coherent structures

\section{1.はじめに}

奏河川においては，河床波，蛇行などの自然的な 要因および堰，ゲート，トレンチなどの人工的な要 因によって不連続な境界が形成される。 その中でも 近年トレンチは流送土砂制御の目的でだけでなく， 河川における環境維持の目的より多自然型河川工法 の一つとして設置されている。また，トレンチに類 似する流れ場を形成するワンドも，環境にやさしい という観点から非常に注目されている。このように トレンチ・ワンドはこれからの「瀬・淵」を含めた 水工設計に尔かせないものとなろう。

一方，水理学的に見ても，開水路キャビティ一流 れは, 剥離せん断層の発達, 組織渦の発生・発達・ 崩壊，あるいは逆流域，死水域の存在といったよう な複雑な乱流場を形成し, 非常に興味深い局所流と なる.

Knisely \& Rockwell ${ }^{1}$ は，下流衝突端のあるキャビ ティー流れにおいてLDAを用いた乱流計測とともに 水素気泡法による組織渦の可視化を行った. その結 果, 下流衝突端のない通常の段落ち流れと比較して 乱れ強度が50\%から $80 \%$ 低减することおよび，この 現象は下流端からかなり上流側の領域でも起こるこ と, また, キャビティ一上流端から発生する剥離渦 が下流端に衝突する位置は規則的に変化することを
指摘寸るとともに, 流れの 3 次元性についても考察 している.

藤田ら ${ }^{2)}$ ３) はトレンチのアスペクト比 $(L / H ， こ$ こにLはトレンチの流下方向長さ，Hはトレンチ高 さを示す) 5 ～10と比較的大きい形状のトレンチにお いて, PIV(Particle Image Velocimetry), LES(Large Eddy Simulation)によりせん断層内においては運動量 と渦度に対し凍結乱流の仮定がほぼ成立するが，移 流速度は平均流速の $60 \%$ ～80\%程度であること，そ してキャビティー内部では底面に近づくにつれて流 れの3次元性が強まることを明らかにした.

襧津ら ${ }^{4)}$ はアアペクト比0.5〜7の帅状のトレンチ においての水理条件一定の下では，あるアスペクト 比の場合において乱れ強度，レイノルズ応力ともに ピーク值をとり,この時トレンチ幅の増加に伴い減 少していたストローハル数がジャンプを起こし，流 体混合が活発となり，この後トレンチ幅の増加とと もに再び減少を始めることを示し，キャビティー形 状の違いにより独自の特性を持つ組織構造の存在を 確認した。

以上のような非定常性， 3 次元性, 非等方性を有 するキャビティー流れを数值シミュレーションする には $k-\varepsilon$ モデルのような時間平均, 等方性の仮定 を必要とするモデルは不的確でありLESが最適であ る.しかし，開水路流におけるその予測精度につい て高精度な実験值との比較, 検証はほとんど行われ 
について高精度な実験值との比較, 検証はほとん ど行われていない。そこで，本研究においてはト レンチ幅の変化によって平均流速, 乱流統計量が 大きく異なる場合を対象にLESによる数值実験を行 いファイバーレーザー流速計(FLDA)による実験結 果と比較検討し, さらにその乱流構造 - 非定常特 性を解明するものである.

\section{2. 数値解析}

\section{（1）基喏方程式}

1 方程式モデルのLESの基礎方程式は以下のよう に表せる。

$$
\begin{gathered}
\frac{\partial \overline{u_{i}}}{\partial x_{i}}=0 \\
\frac{\partial \overline{u_{i}}}{\partial t}+\overline{u_{j}} \frac{\partial \overline{u_{i}}}{\partial x_{j}}=\Omega_{i}-\frac{\partial}{\partial x_{i}}\left\{\frac{\bar{p}}{\rho}+\frac{2}{3} K\right\} \\
+v \frac{\partial^{2} \overline{u_{i}}}{\partial x_{j}^{2}}-\frac{\partial \tau_{i j}}{\partial x_{j}} \\
\frac{\partial K}{\partial t}+\overline{u_{j}} \frac{\partial K}{\partial x_{j}}=2 v_{T} \bar{D}^{2}-C_{\varepsilon} \frac{K^{2 / 3}}{\Delta} \\
+\frac{\partial}{\partial x_{j}}\left\{\left(\frac{v_{T}}{\sigma_{k}}+v\right) \frac{\partial K}{\partial x_{j}}\right\} \\
\Omega_{i}=(g \sin \theta,-g \cos \theta, 0), \quad K=\frac{1}{2} \overline{u_{i}^{\prime} u_{i}^{\prime}}, \quad v_{T}=C_{v} \Delta K^{1 / 2}, \\
\tau_{i j}=-v_{T}\left(\frac{\partial \overline{u_{i}}}{\partial x_{j}}+\frac{\partial \overline{u_{j}}}{\partial x_{i}}\right), \quad \Delta=\left(\Delta_{1} \Delta_{2} \Delta_{3}\right)^{1 / 3}, \\
\bar{D}=\left(\overline{D_{i j}} \overline{D_{i j}}\right)^{1 / 2} \text { ただし, } D_{i j}=\frac{1}{2}\left(\frac{\partial u_{i}}{\partial x_{j}}+\frac{\partial u_{j}}{\partial x_{i}}\right), \\
C_{v}=0.05, \quad \sigma_{k}=0.5, \quad C_{\varepsilon}=1.0
\end{gathered}
$$

ここで $u_{i}$ は $i$ 方向の速度成分 $(i=1,2,3), x_{1}(x)$ は流 下方向， $x_{2}(y)$ は流下垂直上向き方向， $x_{3}(z)$ は横断 方向, 一 は空間平均を施した值, ‘空間平均から のずれ， $\Delta$ はフィルター幅， $p$ は圧力， $\rho$ は密度， $\mathrm{g}$ は重力加速度, $\sin \theta$ は河床勾配, $v$ は動粘性係数 をそれぞれ示し，繰り返し添え字は縮約規約に従 うものとする。

式 (1) は連続式, 式 (2) は運動方程式, 式 (3) は subgrid scaleの乱流エネルギー $K$ の輸送方程式であ る.

\section{（2）数值解析手法}

本研究では, 差分スキームは時間に対して2次精 度のAdams-Bashforth法, 空閒に对しては2次精度の 中心差分を用いた. 差分アルゴリズムとしてSMAC 法を使用し, 速度ポテンシャルの計算は共役残差 法により解いた。メッシュ系はスタガードグリッ

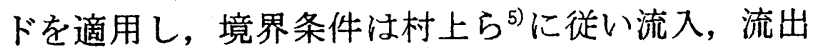
面において主流, 横断方向に周期境界条件, 壁面 においてはno-slip条件，水面においては対称条件を 用いた。

\section{（3）計算条件}

本研究におけるトレンチの形状及び座標系を図一 1に示す. また各ケースの水理条件を表一に示す. ここにQは流量, hは水深, $R e=U_{m} R / v$ はレイノル ズ数, $U_{m}$ は断面平均流速，Rはトレンチ上流部に おける径梁, $F r=U_{m} / \sqrt{g h}$ はフルード数である。ま た無次元時間 $T=R / U_{m}=1$ は実時間で0.52秒である. 格子分割は $x, y, z$ 方向についてそれぞれV10は $56 \times$ $32 \times 20$, V30は $74 \times 32 \times 20$ ᄂ L. .

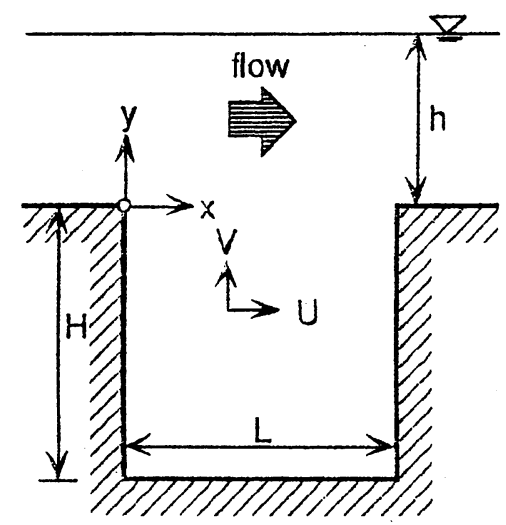

图-1トレンチ形状と座標系

\begin{tabular}{|l|c|c|c|c|l|l|}
\hline CASE & $Q(1 / \mathrm{s})$ & $h(\mathrm{~cm})$ & $L(\mathrm{~cm})$ & $L / H$ & $R e$ & $F r$ \\
\hline V10 & 2.5 & 6.6 & 6.6 & 1.0 & 4700 & 0.12 \\
\hline V30 & 2.5 & 6.6 & 19.8 & 3.0 & 4700 & 0.12 \\
\hline
\end{tabular}

\section{3. 解析結果}

本研究における実験值と比較する平均諸量は, 計算開始から15万ステップ経過後ほぼ流れが定常 に達しているのを確認し, その後の3000ステップ (無次元時間で約57)のアンサンブル平均を取り乱 流量等を計算した值である。なお，ここでの流下 方向，流下垂直上向き方向についてそれぞれ時間 平均流速を $U, V$ レイノルズ応力を- $\overline{u v}$, 乱流エネ ルギーを $k$ とし初期断面の最大流速 $U_{\max 0}$ で無次元 化している.

\section{（1）時間平均流速分布特性}

図-2,3 3 平均流速のベクトル図である。V10, V30ともキャビティー内部の組織渦の存在が確認で きるがV100ほうはトレンチ内部がほとんど死水域 になっているのに対しV30のケースではトレンチ界 面において混合層の広がりを示唆している。また 図-4, 5, 6, 7は流下方向への流速分布の変化を示寸 図であり，図-8,9はV30における平均主流速のコン ター図である。これらよりFLDAにおいて特徵的な， V30はV10よりも逆領域がより下流に現れる点， 


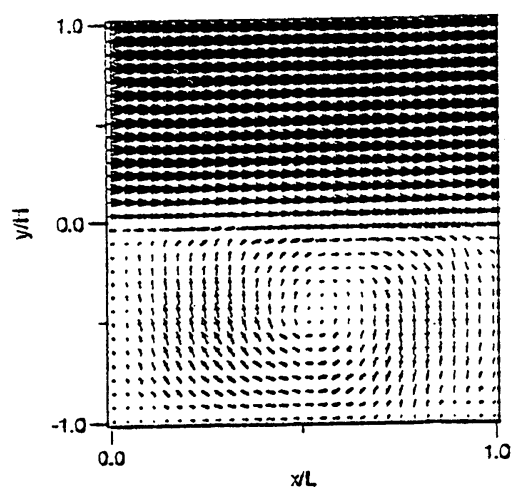

图-2 平均流速のベクトル (V10) 計算結果

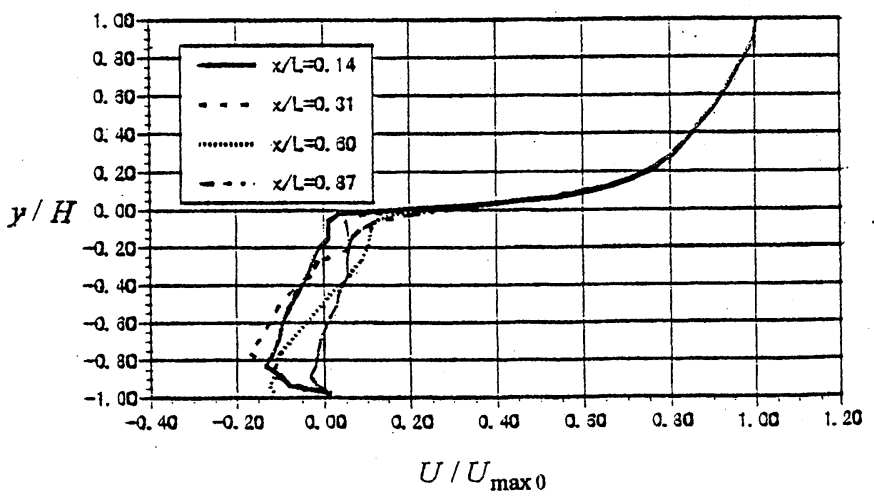

図-4 平均流速の流下方向变化 (V10) 計算結果

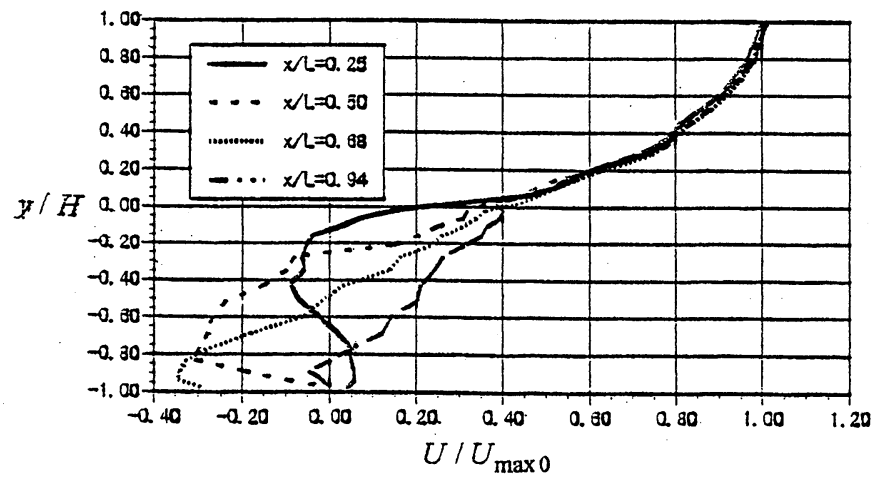

図-6 平均流速の流下方向変化 $(\mathrm{V} 30)$ 計算結果

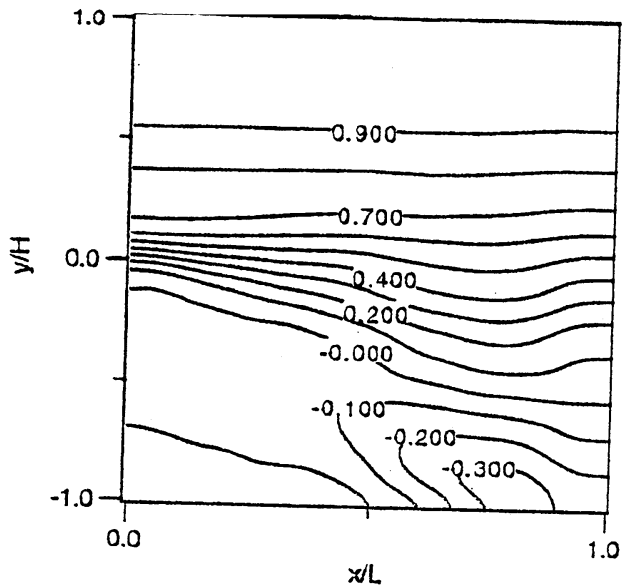

图-8 平均主流速のコンター（V30）計算結果

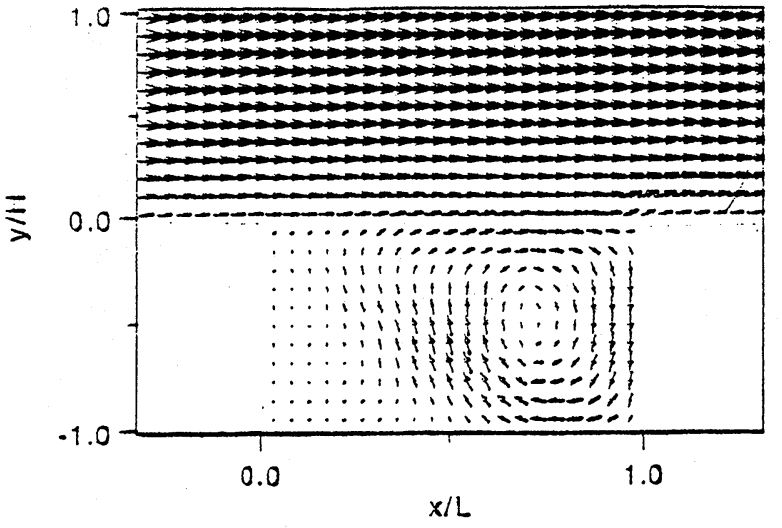

图-3 平均流速のベクトル（V30）計算結果

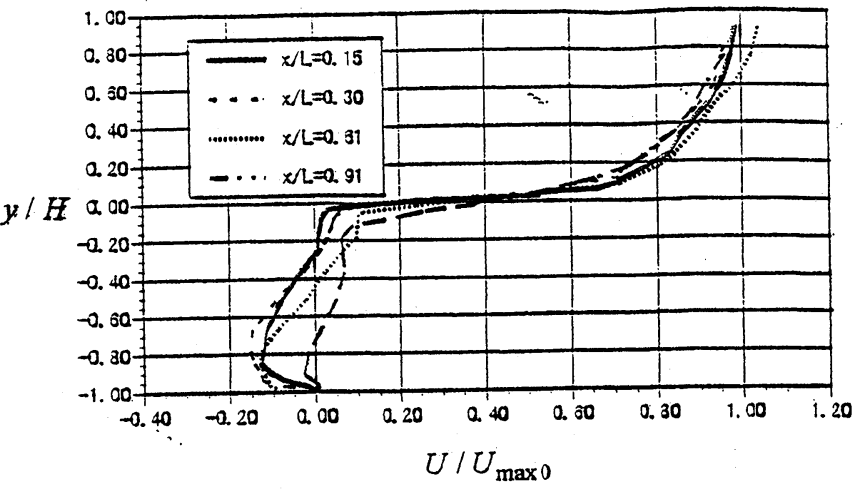

図-5 平均流速の流下方向変化 (V10) 実験結果

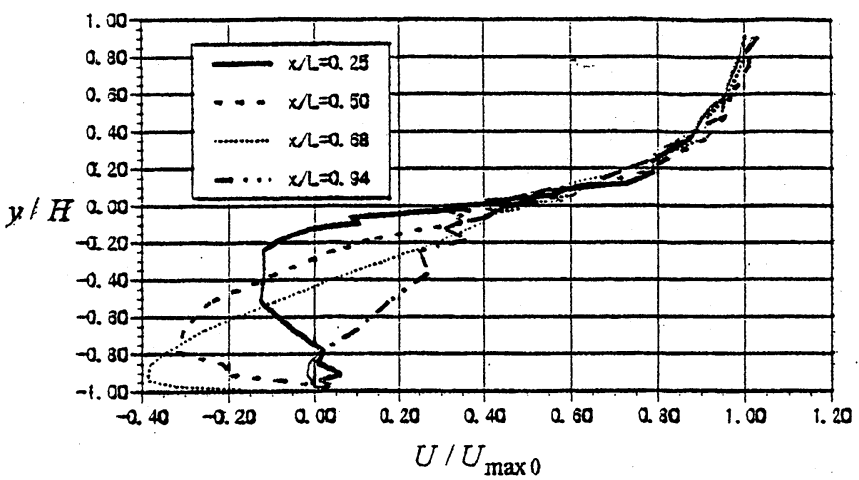

図-7 平均流速の流下方向变化 $(\mathrm{V} 30)$ 実験結果

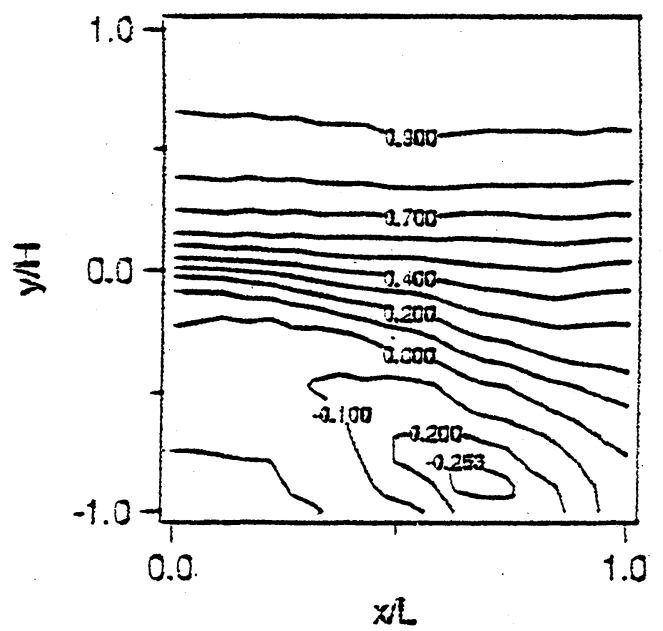

图-9 平均主流速のコンター（V30）実験結果 


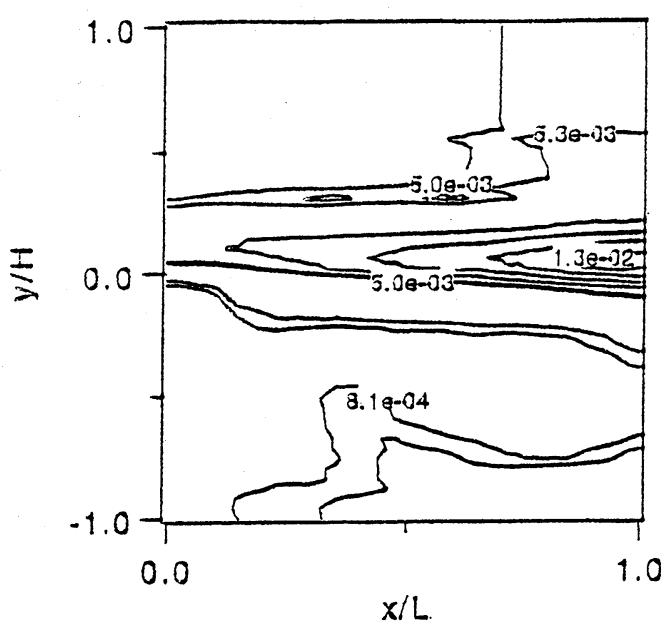

図-10 乱れエネルギーのコンター（V10）計算結果

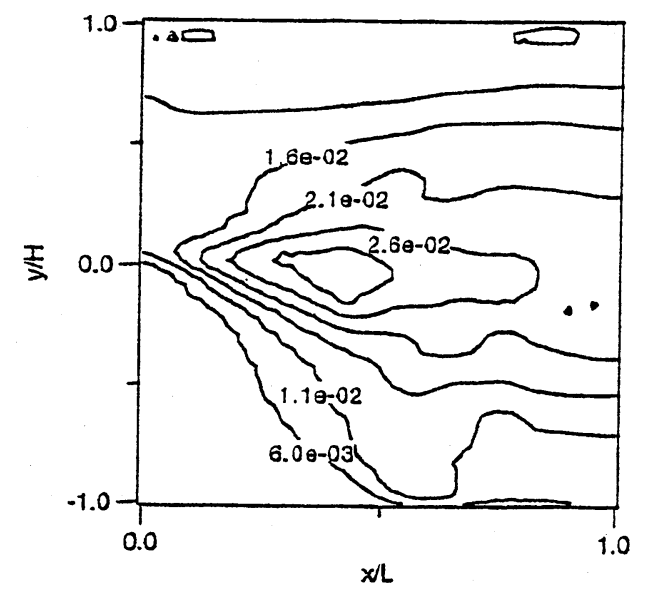

図-12 乱れエネルギーのコンター（V30）計算結果

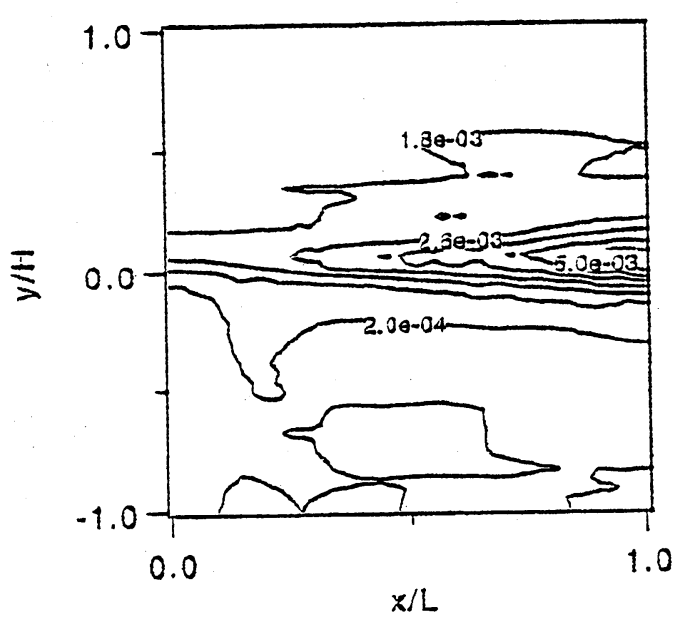

图-14 レイノルズ忘力のコンター（V10）計算結果

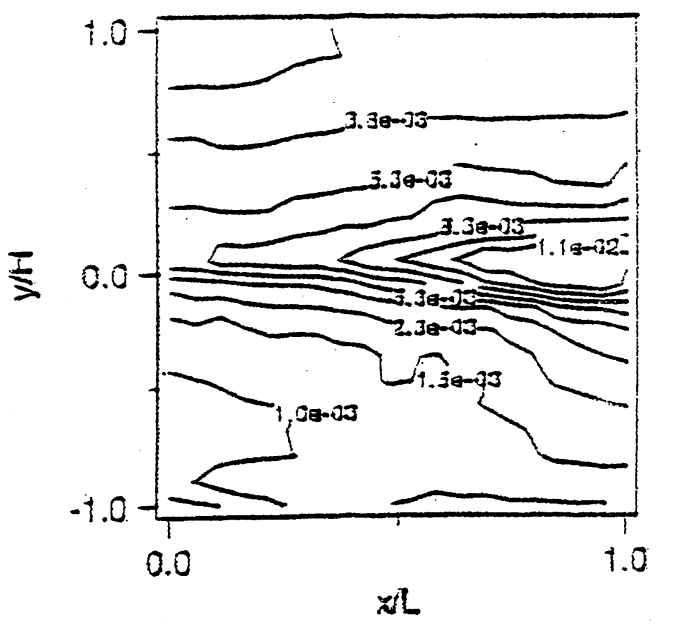

図-11 乱れエネルギーのコンター（V10）実験結果

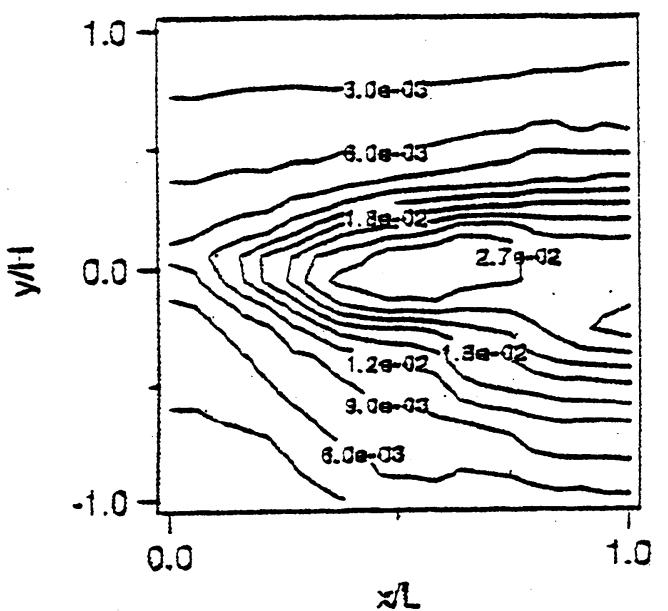

図-13 乱れエネルギーのコンター（V30）実験結果

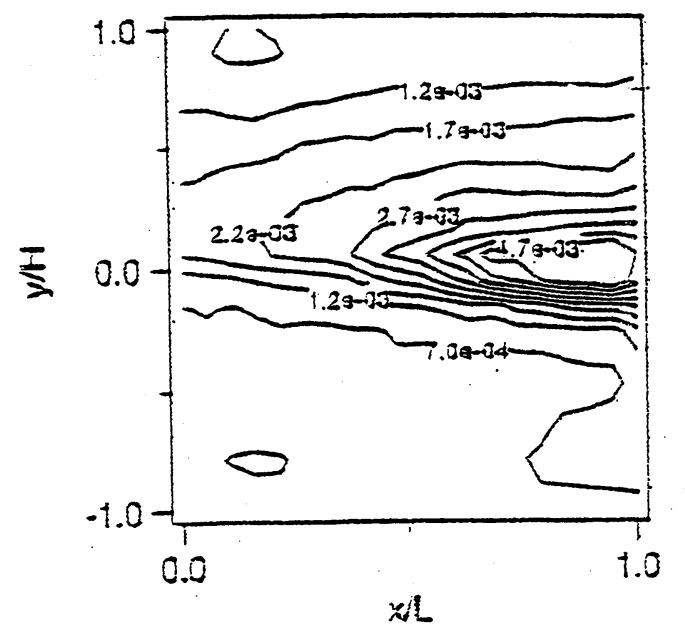

図-15 レイノルズ応力のコンター（V10）実験結果 


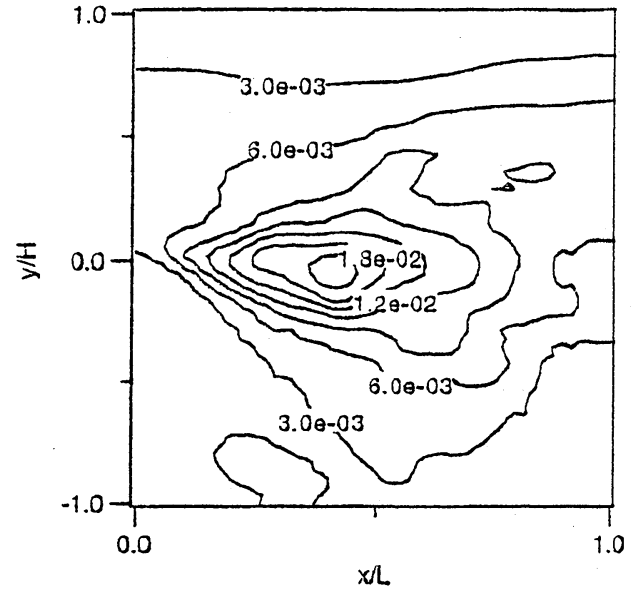

図-16レイノルズ応力のコンター（V30）計算結果

またキャビティー内部においてはV30のほうが逆 流が強い点がLESにより傾向, 值とも再現できてい るが，V30のコンター図においてLES活FLDAに比べ 上流側のトレンチ壁面近くで分布形が少しずれて いる.

\section{（2）乱叔就計量の分布特性}

図-10〜17は乱れエネルギー，レイノルズ応力の コンター図である、V10についてはレイノルズ応, 乱れ強度ともにトレンチ界面の下流端付近でピー ク值をとる点や流体混合がトレンチ界面近傍のみ で行われている傾向が定性的・定量的に再現でき ている、V30においては, トレンチ上流端付近で LESはやや乱れの広がりを抑制されている点や，ま た上流付近の水面近傍でも不連続な部分が見られ る.

これらについては，境界条件や格子幅などの諸 条件をもう一度検討してみる必要があると思われ るが, 乱れエネルギーがトレンチの界面中央と下 流端付近で2つのピーク值をとる点や界面を中心と して流下方向に扇状に広がって行く点など值, 傾 向がよく表現できている。トレンチ形状の違いに よる乱流構造の違いを良好に計算できている。レ イノルズ応力についても同様の傾向が見られる.

\section{(3) 組繶渦構造}

\section{a) 組織渦の発生・発達機構}

トレンチのアスペクト比の変化により乱れ強度, レイノルズ応力がピーク值をとるV30における流れ はキャビティー上流端で剥離した流れがロール アップするまでの領域である線形領域と，ロール アップを起こした後の組織的な渦構造が発達して いく非線形領域に分けられる。 その組織構造は, 剥離渦の発生周期と循環渦の大きさ・中心位置に より，ある過程を何回も重複したり，さらには， 省略しながら反復しているが, 剥離渦と下流端付 近の大きな循環渦との関佂により以下のようなパ ターンを繰り返している.

(1) トレンチ下流部に存在する大きな循環渦 (図-

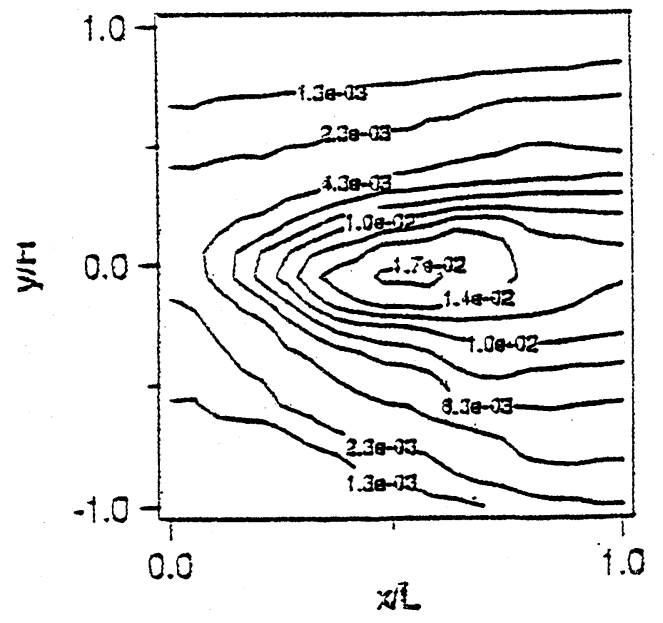

図-17レイノルズ忘力のコンター（V30）実験結果

18）に無次元時間で3〜4間隔で発生する剥離渦が トレンチ中央からやや上流側で衝突し(図-19), この剥離渦を連行し大きな循環渦が下流端に移 動し一部はトレンチ外部に放出され, 一部はト レンチ内部に引き込まれる(图一20).

（2）またトレンチ下流側へ押しやられた循環渦に 次の剥離渦が流下し二つの渦がトレンチ中央やや 下流側で衝突し(图-21) 再び大きな循環渦を形成す る.

(3)さらにこの循環渦は，トレンチ界面付近の流 体を巻き込み(図-22)さらに大きな循環渦を形成し 再び(1)に戻る。

このような過程はKnisely \& Rockwell ${ }^{1)}$ の指摘する 剥離渦の下流端に衝突する位置は規則的に変化す ることと関連があると思われる。この様に明瞭に 渦の発生・発達をとらえた研究はほとんどないた め, 今後詳細に調べる必要がある。

\section{b) 組織渦の乱流統計量に及ぼす影翌}

V30のケースにおいては乱れ強度がトレンチ中央 部と下流端において2つのピーク值をとるが，これ は上記の過程により剥離渦と循環渦が衝突する中 心部とその連行により下流端に衝突する部分に相 当すると思われる。

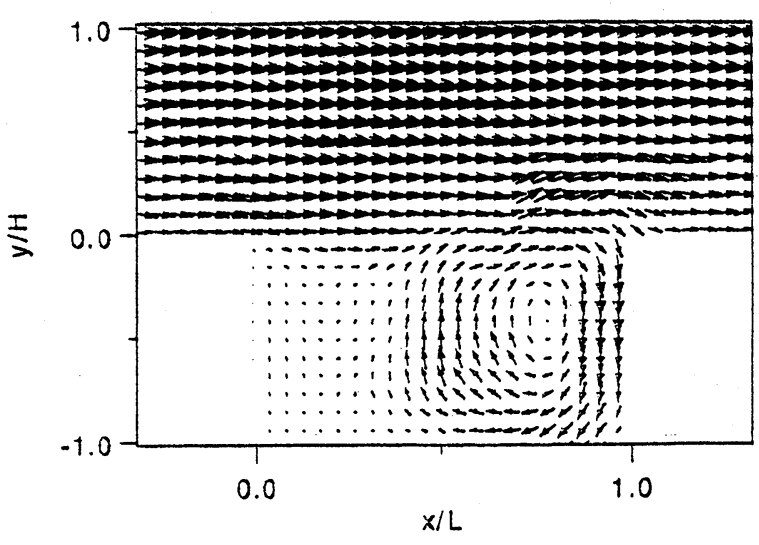

図-18 循環渦 


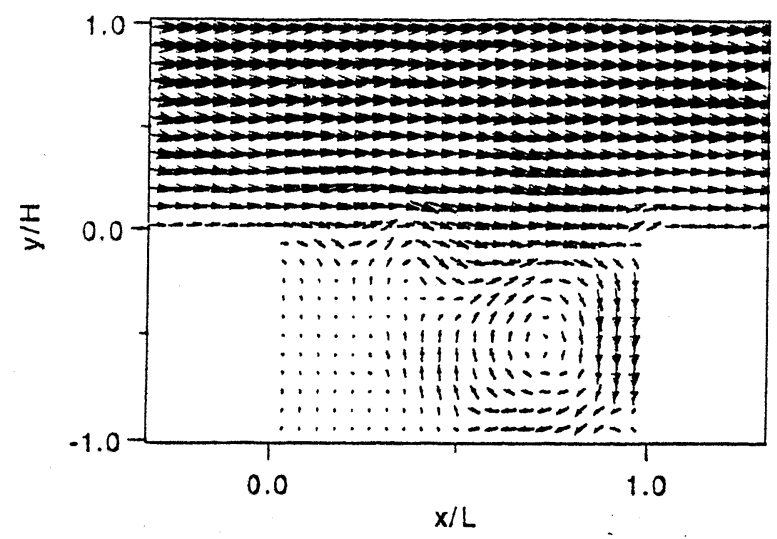

図-19 剥離渦と循環渦の衝突 1

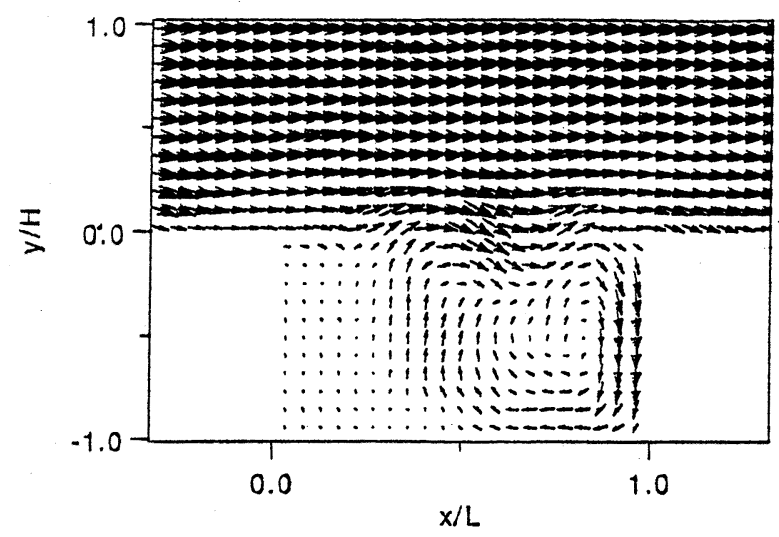

図-21 剥離渦と循環渦の衝突 2

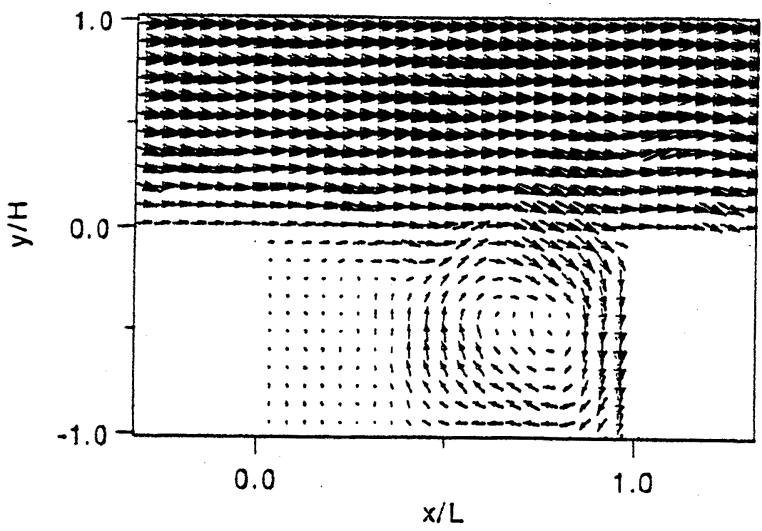

図-20 偱環渦のトレンチ下流端への衝突

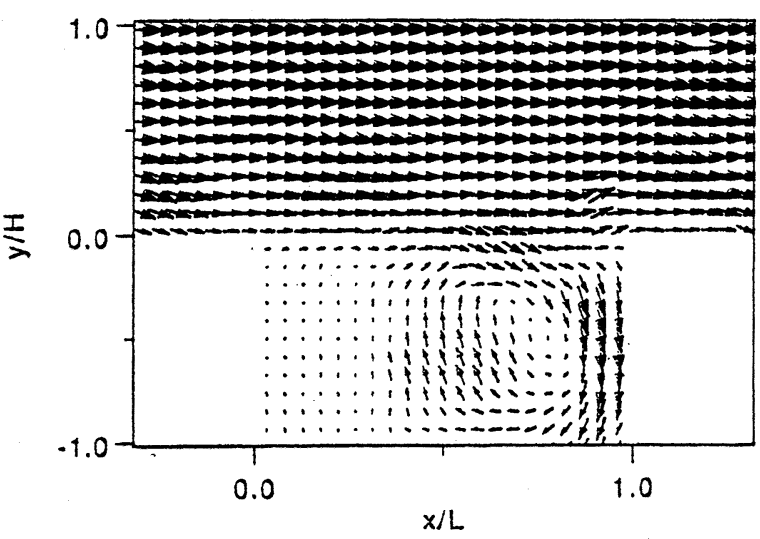

図-22トレンチ界面付近の流体の巻き込み

\section{4. 結論}

本研究において, 開水路キャビティーせん断乱 流をLESにより数值シミュレーションを行い, その 平均諸量をFLDAによる実験結果と比較・検討しさ らにその乱流構造や非定常性について解明し以下 の上うな結論が得られた。

(1) LESはFLDAによって得られたトレンチ幅の変化 による平均流速, 乱れエネルギー, レイノルズ応 力の分布特性や值の変化を良好に再現できる.

(2)乱れエネルギー，レイノルズ応力の乱流統計量 については局所的な部分についてはややずれる傾 向が見られるが全体的な分布特性や值は一致する。

(3)トレンチ幅の変化により乱れエネルギー，レイ ノルズ応力がピークをとるケースにおいては，剥 離渦の発生周期と循環渦の大きさ中心位置との関 連によりいくつかの過程を反復していることが初 めて分かった。

（4）剥離渦と大きな循環渦が衝突するトレンチ中央 部とその連行による渦のトレンチ下流端に衝突寸 る現象は同様の場所において乱れエネルギー、レ イノルズ応力がピークをとることと関係している と思われる。

(5) 本計算は比較的粗い格子を用いてのLESである
ので格子平均で失われる渦運動成分があると考え られ, 非定常性の定量的な面においては今後詳細 に調べる必要があると思われる。

謝辞 : 本研究を行うにあたり, 京都大学大学院環 境地球工学教室助手平岡久司先生に多大なるご協 カとご助言を頂いた。ここに，謝意を表する。

\section{参考文献}

1)Knisely, C. and Rockwll, D. : Self-sustained low-frequency components in an impinging shear layer, J. Fluid Mech., Vol. 16, pp.157-186, 1982.

2) 藤田一郎・神田徹・門脇正夫・海津利幸 : PIVによるト レンチ内流れの乱流特性の解析, 第26回乱流シンポジ ウム講演会論文集, pp. 96-99, 1994.

3) 藤田一郎・神田徹・森田卓光 : LESによる開水路CAVITY 内流れの乱流特性の解析, 第26回乱流シンポジウム講 演会論文集, pp. 334-337, 1994.

4) 襧津家久・門田章宏・高津昌夫・井上憲 : 開水路キャ ビティーせん断首の乱流構造と組織渦の発生機構, 水 工学論文集, 第40巻, pp. 761-766, 1996.

5)村上周三・持田灯・日比一喜 : Large Eddy Simulationk よる街区周辺の乱流場の解析, 第3回生研NSTシンポジ ウム講演論文集, pp. 73-77, 1988.

(1997. 9. 30受付) 